\title{
Effects of protozoan grazing on colony formation in Phaeocystis globosa (Prymnesiophyceae) and the potential costs and benefits
}

\author{
Hans H. Jakobsen*, Kam W. Tang** \\ Danish Institute for Fisheries Research, Kavelergården 6, Charlottenlund 2920, Denmark
}

\begin{abstract}
Colony formation by Phaeocystis globosa was enhanced in terms of colony size when solitary P. globosa cells were grazed by the heterotrophic dinoflagellates Noctiluca scintillans and Gyrodinium dominans. Enhancement of colony size in the grazing treatment was evident after 5 to $8 \mathrm{~d}$. Grazing by N. scintillans increased the mean colony size by up to $50 \%$ relative to the controls, whereas grazing by $G$. dominans enhanced the mean colony size by up to 3 -fold. Microscopic observations confirmed that $N$. scintillans was also able to ingest small colonies. In contrast, G. dominans apparently did not ingest colonies, and in most cases the abundance of colonies was also increased in the grazing treatment. Up to $92 \%$ of $P$. globosa cells were in colonial form when $G$. dominans was present, in contrast to $<31 \%$ in the controls. Enhanced colony formation provided refuge for P. globosa cells such that $G$. dominans starved and declined after the initial depletion of solitary P. globosa cells. Slow recovery of starved grazers subsequently allowed solitary $P$. globosa cells to resume exponential growth. The apparent specific growth rate of colonial P. globosa cells was not different from that of solitary cells; thus, the costs of colony formation must be sought elsewhere.
\end{abstract}

KEY WORDS: Defense theory $\cdot$ Harmful algal bloom · Toxicity $\cdot$ Diffusive boundary layer $\cdot$ Pelagic food web

Resale or republication not permitted without written consent of the publisher

\section{INTRODUCTION}

In aquatic ecosystems, a phytoplankter's defense capability against grazers not only has immediate effects on its own survival, but also bears consequences on competition and trophic cascades within the systems (Agrawal 1998). Two of the most frequently discussed defense strategies are chemical defense and morphological defense. Chemical defense invokes the production of extra- or intracellular chemicals that act to deter predators (Berenbaum

\footnotetext{
*Present address: Shannon Point Marine Center, Western Washington University, 1900 Shannon Point Road, Anacortes, Washington 98221, USA

${ }^{* *}$ Corresponding author. E-mail: kta@dfu.min.dk
}

1995, Hay 1996). In a spatially variable and dynamic planktonic system, diffusive loss of extracellular defense chemicals in the medium would render the strategy costly and inefficient. Diffusion of extracellular defense chemicals also poses the problem of 'distributed benefits' to the producers, putting them in a disadvantageous position relative to their competitors (Lewis 1986). Since unicellular phytoplankters are usually engulfed whole, a defense strategy that involves intracellular chemicals (e.g. toxin) would be favorable only if the chemicals exert their effects before ingestion takes place. Thus, unless behavioral avoidance of chemically defended cells by grazers can be demonstrated, the adaptive significance of intracellular chemical defense mechanism is debatable. These arguments do not refute the harmful effects phytoplankters may have on grazers, but 
they call into question the evolution of antagonistic chemical interactions in the planktonic systems (Lewis 1986).

Morphological defense, on the other hand, is perceivably more favorable in an evolutionary context since this strategy benefits only the individuals that invest in such a defense. Among aquatic phytoplankters, morphological defense usually involves the production of protective external structures, such as siliceous or calciferous shells and spines in diatoms and forams. Another means of morphological defense is to increase in size to beyond the handling capacity of the predators. A well-studied example is the colonyforming chlorophyte Scenedesmus sp., which often dominates in freshwater systems. Colony formation in Scenedesmus sp. greatly increases when the solitary cells are grazed upon by Daphnia sp. (Lürling \& van Donk 1997, Lürling 1999), and the effect is mediated by infochemicals released during the grazing process (Lürling \& van Donk 1997, Lürling 1998). Defense theory dictates that any defense should be associated with a cost to the organisms (Mole 1994, Agrawal 1998). In the case of Scenedesmus sp., colonial cells suffer from a reduced specific light absorption coefficient (Lürling 1999) or a higher sinking rate than the solitary cells (Lürling \& van Donk 2000).

In marine systems, a good candidate for the study of morphological defense is colony-forming Phaeocystis sp. (Prymnesiophyceae). Phaeocystis is a globally distributed genus that often dominates the local phytoplankton communities (Lancelot et al. 1998). The complex life cycle of Phaeocystis sp. involves an alternation between solitary cells of a few micrometers and mucilaginous colonies of up to a few millimeters in size (Rousseau et al. 1994). Much remains unknown of the biological roles of different life stages and the regulation of transitions between stages (Rousseau et al. 1994, Lancelot et al. 1998). Nevertheless, the prevalence of the colonial form in natural Phaeocystis sp. blooms in contrasting water types prompts the ideas that Phaeocystis sp. colony formation is regulated by common factors (Lancelot \& Rousseau 1994) and that it contributes to the species' success in marine systems (Rousseau et al. 1994, Lancelot et al. 1998). Although data are still scanty, protozoans have been shown to graze on Phaeocystis sp. solitary cells, sometimes at high rates (Weisse \& Scheffel-Möser 1990, Hansen et al. 1993, Verity 2000, Tang et al. 2001). Thus, it has been speculated that colony formation in Phaeocystis sp. is a defense strategy against grazing due to size mismatch between the colonies and the protozoans, and mechanical protection by the colony's mucous envelope (Weisse et al. 1994, Lancelot et al. 1998, Hamm et al. 1999, Ploug et al. 1999). Such an argument begs for evidence that grazing on solitary cells enhances colony formation in Phaeocystis sp., which in turn increases the survival of Phaeocystis sp. cells. Yet, to our knowledge, such evidence has been missing. Despite the wide-ranging environmental impacts of dense Phaeocystis sp. blooms, Phaeocystis sp. is generally not considered a toxin producer. However, there is evidence that Phaeocystis sp. may be harmful to other aquatic organisms under laboratory conditions (Aanesen et al. 1998, Stabell et al. 1999). Although these reportedly harmful effects do not necessarily constitute an argument for the evolution of chemical defense in Phaeocystis sp., they may nonetheless reduce grazing pressure and facilitate bloom formation.

The goal of the present study was thus to investigate whether protozoan grazing of solitary cells enhances colony formation in Phaeocystis sp., the subsequent effects on the protozoan grazers and whether there is a cost associated with colony formation as predicted by the defense theory. We also tested the possibilities that Phaeocystis sp. cells have direct negative effects on the protozoans under defined conditions. For the present study we used Phaeocystis globosa, one of the most widely distributed Phaeocystis species in the world's oceans (Lancelot et al. 1998). For grazers we used 2 cosmopolitan naked heterotrophic dinoflagellates, Gyrodinium dominans and Noctiluca scintillans, which are commonly found in areas infested by Phaeocystis sp. G. dominans is an important grazer in coastal waters (Hansen 1991, Nakamura et al. 1995, Naustvoll 2000), and a previous laboratory study has shown that G. dominans feeds and grows efficiently on P. globosa solitary cells (Tang et al. 2001). High abundance of $N$. scintillans has been reported during and after a Phaeocystis sp. bloom (Weisse \& Scheffel-Möser 1990, Frangoulis et al. 2001) and there is also some evidence that $N$. scintillans can graze on Phaeocystis sp. solitary cells (Weisse \& Scheffel-Möser cited in Weisse et al. 1994). Thus, it is of ecological interest to investigate how grazing by these protozoan species affects colony formation in P. globosa.

\section{MATERIALS AND METHODS}

Phytoplankton and grazers. A non-axenic strain of Phaeocystis globosa (CCMP 1528) was obtained from the Bigelow Laboratory, West Boothbay Harbor, ME, USA. A batch culture of $P$. globosa was grown in Lmedium (Guillard \& Hargraves 1993) at $19 \pm 1^{\circ} \mathrm{C}, 60$ to $100 \mu \mathrm{mol}$ photons $\mathrm{m}^{-2} \mathrm{~s}^{-1}$ in a $12 \mathrm{~h}$ light: $12 \mathrm{~h}$ dark cycle. The culture was maintained in exponential growth phase by regular dilution with fresh medium. A culture of Noctiluca scintillans originating from the California coast was kindly provided by Dr. Peter von Dassow (Scripps Institution of Oceanography, La Jolla, CA, 
USA) and was maintained in L-medium on a diet of Rhodomonas salina (Cryptophyceae). Gyrodinium dominans culture was originally isolated from the Øresund, Denmark, and maintained in L-medium on a diet of Dunaliella tertiolecta (Chlorophyceae). The equivalent spherical diameters (mean $\pm \mathrm{SD}$ ) of the grazers are $1.3 \pm 0.18 \mathrm{~mm}$ and $15 \pm 1 \mu \mathrm{m}$ for N. scintillans and G. dominans, respectively. Batch cultures of $D$. tertiolecta and $R$. salina were maintained in exponential growth in L-medium; aliquots were added to G. dominans and $N$. scintillans in frequent, but small, amounts such that accidental transfer of residual food to the experimental vessels was negligible.

Before the experiments, solitary Phaeocystis globosa cells were collected by passing the phytoplankton culture twice through an $11 \mu \mathrm{m}$ sieve under gravity. Preliminary tests showed that only a few small colonies (mostly $<20 \mu \mathrm{m}$ in diameter) were able to pass through the sieve, and colonial cells made up $<0.3 \%$ of the total cells in the final medium. Thus, this procedure is an easy and effective way to separate solitary cells from colonies. All experimental incubations were done on a rotating plankton wheel $(0.4 \mathrm{rpm})$ at $19 \pm 1^{\circ} \mathrm{C}, 75 \mu \mathrm{mol}$ photons $\mathrm{m}^{-2} \mathrm{~s}^{-1}$ in a $12 \mathrm{~h}$ light: $12 \mathrm{~h}$ dark cycle.

Grazing effects on colony development-Noctiluca scintillans (Noc experiments). Noctiluca scintillans was picked from culture individually, rinsed briefly in L-medium and added to the grazing bottles (120 to $135 \mathrm{ml}$ in triplicate) with $10^{4}$ Phaeocystis globosa solitary cells $\mathrm{ml}^{-1}$ in L-medium. The experiment was conducted twice with different concentrations of $N$. scintillans (Table 1). The final cell concentrations of $N$. scintillans were comparable to the natural concentrations of a Noctiluca sp. bloom (Schoemann et al. 1998). In each experiment triplicate bottles without $N$. scintillans were used as controls. Each bottle was sampled periodically for $P$. globosa solitary cell and colony concentrations, and colony size (see below). Our hypothesis was that grazing by $N$. scintillans enhances $P$. globosa colony concentration and colony size.

Grazing effects on colony development-Gyrodinium dominans (Gyro experiments). The experi- ment was conducted twice with different concentrations of Gyrodinium dominans and Phaeocystis globosa solitary cells in L-medium (620 ml bottles in triplicate) (Table 1). The resultant predator-to-prey ratios are within the range of observed ratios between heterotrophic dinoflagellates and Phaeocystis sp. solitary cells in nature (Weisse \& Scheffel-Möser 1990, Stoecker et al. 1995). In each experiment, triplicate bottles without G. dominans were used as controls. Each bottle was sampled periodically for G. dominans concentration, P. globosa solitary cell and colony concentrations, and colony size. On several occasions we also estimated the number of cells per colony (see below). Our hypothesis was that grazing by G. dominans enhances P. globosa colony concentration and colony size.

Toxicity experiment. In the colony development experiments, we observed that Gyrodinium dominans eventually died off in the grazing bottles. Thus, in a follow-up experiment, we asked the question whether Phaeocystis globosa developed intracellular toxicity after exposure to grazing. We first incubated P. globosa solitary cells $\left(2 \times 10^{4} \mathrm{ml}^{-1}\right)$ with $G$. dominans $\left(400 \mathrm{ml}^{-1}\right)$ for $9 \mathrm{~d}$ (in triplicate), then collected the 'grazeradapted' solitary cells for subsequent incubations. New G. dominans $\left(260 \mathrm{ml}^{-1}\right)$ were incubated with either the grazer-adapted cells or 'reference cells' that had not been exposed to grazers $\left(2 \times 10^{4} \mathrm{ml}^{-1} P\right.$. globosa cells in triplicate). We followed the growth of G. dominans for $2 \mathrm{~d}$, and our hypothesis was that if $P$. globosa developed intracellular toxicity after initial exposure to grazers, then $G$. dominans incubated with the grazer-adapted cells would have lower growth than G. dominans incubated with the reference cells.

Starvation and recovery experiment. Colony formation by Phaeocystis globosa may deprive protozoan grazers of food once the solitary cells are depleted. We conducted experiments to investigate whether protozoan grazers could recover after depletion of $P$. globosa solitary cells. We first mixed a high concentration of Gyrodinium dominans $\left(\sim 800 \mathrm{ml}^{-1}\right)$ with P. globosa solitary cells $\left(10^{4} \mathrm{ml}^{-1}\right)$ in triplicate bottles. After depletion of the solitary cells due to grazing, we allowed G. dom-

Table 1. Initial conditions of experiments to investigate the effects of protozoan grazers on Phaeocystis globosa colony development. All experiments were run in triplicate with parallel grazer-free controls

\begin{tabular}{|c|c|c|c|c|c|}
\hline Expt & Grazer species & $\begin{array}{l}\text { Grazing } \\
\text { intensity }\end{array}$ & $\begin{array}{l}\text { Grazer conc. } \\
\left(\text { cells } \mathrm{ml}^{-1}\right)\end{array}$ & $\begin{array}{l}\text { P. globosa solitary } \\
\text { cells (cells ml }{ }^{-1} \text { ) }\end{array}$ & $\begin{array}{l}\text { Predator-to- } \\
\text { prey ratio }\end{array}$ \\
\hline Noc 1 & Noctiluca scintillans & Low & 3 & $10^{4}$ & $1: 3333$ \\
\hline Noc 2 & Noctiluca scintillans & High & 10 & $10^{4}$ & $1: 1000$ \\
\hline \multirow[t]{2}{*}{ Gyro 1} & \multirow{2}{*}{ Gyrodinium dominans } & Low & 3 & $3 \times 10^{3}$ & 1:1000 \\
\hline & & High & 30 & $3 \times 10^{3}$ & $1: 100$ \\
\hline \multirow{2}{*}{ Gyro 2} & \multirow{2}{*}{ Gyrodinium dominans } & Low & 200 & $2 \times 10^{4}$ & $1: 100$ \\
\hline & & High & 400 & $2 \times 10^{4}$ & $1: 50$ \\
\hline
\end{tabular}


inans to continue to starve for $4 \mathrm{~d}$. We then transferred aliquots of the starving $G$. dominans (150 to $200 \mathrm{ml}^{-1}$ ) to 'recovery vials' $(25 \mathrm{ml})$, fed with high $\left(2 \times 10^{5} \mathrm{ml}^{-1}\right)$ and low $\left(2 \times 10^{4} \mathrm{ml}^{-1}\right)$ concentrations of P. globosa solitary cells for 2 consecutive days, and monitored their recovery growth.

Sample preservation and measurements. For Gyrodinium dominans and Phaeocystis globosa solitary cells, aliquots were drawn with a wide-mouth pipette, preserved in acid Lugol's solution (final conc. $4 \%$ ) and counted in a settling chamber (G. dominans) or a Sedgwick-Rafter counting chamber ( $P$. globosa solitary cells). For $P$. globosa colonies, 1 to $3 \mathrm{ml}$ aliquots were transferred with a wide-mouth pipette to a settling chamber with acid Lugol's solution (final volume $3.5 \mathrm{ml}$, final conc. $4 \%$ ). The colonies were allowed to settle for at least $4 \mathrm{~h}$ before they were counted with an inverted microscope. Twenty to 30 colonies were randomly chosen from each sample and sized with a calibrated ocular meter (200× magnification). Colony size was measured as the diameter across the mucous envelope of the colony. This simple method was adequate for our purpose since the majority of the colonies were in spherical forms (cf. Rousseau et al. 1990). Although the mucous envelopes could be observed without staining, preservation in Lugol's solution facilitated settling of the colonies and made the envelopes more visible in dark field. Preliminary tests showed that $4 \%$ acid

Table 2. (A) Test of effects of acid Lugol's solution on colony count. Colonies were preserved in acid Lugol's solution (final conc. $4 \%$ ) in settling chambers. Colonies were allowed to settle for $\sim 4 \mathrm{~h}$ before the initial count; then recounted after $2 \mathrm{~d}$ at $4^{\circ} \mathrm{C}$ in dark. Difference between initial and final counts was tested by paired $t$-test. (B) Test of effects of acid Lugol's solution on colony diameter. Colonies in the same settling chamber were randomly selected for measurements before, immediately after and $2 \mathrm{~d}$ after adding acid Lugol's solution (final conc. $4 \%$ ). Differences in colony diameters were tested by 1-way ANOVA. SD: standard deviation

\begin{tabular}{|c|c|c|c|}
\hline \multirow{2}{*}{$\begin{array}{l}\text { (A) } \\
\text { Trial }\end{array}$} & \multicolumn{3}{|c|}{ Colonies ml-1 } \\
\hline & Initial & & Final (after $2 \mathrm{~d}$ ) \\
\hline 1 & 288.9 & & 276.0 \\
\hline 2 & 485.4 & & 487.0 \\
\hline \multirow[t]{2}{*}{3} & 319.1 & & 307.7 \\
\hline & \multicolumn{3}{|c|}{ Paired $t$-test; $\mathrm{p}=0.24$} \\
\hline (B) & \multicolumn{3}{|c|}{ No. Diameter $($ mean $\pm \mathrm{SD})$} \\
\hline \multicolumn{2}{|c|}{ Before adding Lugol's solution } & 49 & $67.6 \pm 18.9$ \\
\hline \multicolumn{2}{|c|}{$\begin{array}{l}\text { Immediately after adding } \\
\text { Lugol's solution }\end{array}$} & 74 & $65.6 \pm 18.2$ \\
\hline \multicolumn{2}{|c|}{ After $2 \mathrm{~d}$ in Lugol's solution } & 62 & $65.0 \pm 16.9$ \\
\hline \multicolumn{4}{|c|}{ 1-way ANOVA; $p=0.74$} \\
\hline
\end{tabular}

Lugol's solution effectively preserved the colonies for at least $2 \mathrm{~d}$ (Table 2A) without affecting the colony size (Table 2B). Nevertheless, all samples were analyzed within $1 \mathrm{~d}$. On several occasions we also estimated the number of cells per colony. P. globosa cells lie within the mucous envelope of the colonies. Using a counting grid we measured on an inverted microscope the number of cells per unit surface area, then multiplied it by the total surface area covered by colonial cells, assuming an even distribution of cells on the colony.

\section{RESULTS}

\section{Effects of Noctiluca scintillans on colony development}

In Expt Noc 1, the presence of Noctiluca scintillans had no significant effects on the concentrations of solitary cells and colonies (2-way ANOVA, p > 0.05 for N. scintillans vs control; Fig. 1A,B). The colonies were significantly larger in the grazing bottles than in the controls throughout the experiments (MannWhitney rank sum test, $\mathrm{p}<0.05$ ), but the size difference diminished with time such that the ratio of geometric mean colony diameter between grazing bottles and controls decreased from 1.5 on Day 5 to 1.2 on Day 9 (Fig. 1C).

In Expt Noc 2, where we started with a higher number of Noctiluca scintillans, solitary cell concentration was significantly lower in the grazing bottles throughout the experiment (2-way ANOVA followed by Tukey test, $\mathrm{p}<0.05$ for $N$. scintillans vs control; Fig. 2A). Colony concentration was significantly lower in the grazing bottles from Day 5 to Day 7 (Fig. 2B) but not on Day 9, when the colony concentration began to decline in the controls (2-way ANOVA followed by Tukey test, $\mathrm{p}<0.05)$. Microscopic observations confirmed that $N$. scintillans ingested Phaeocystis globosa solitary cells and colonies (Fig. 3). Colonies in the grazing bottles were initially smaller than colonies in the controls (Day 5, Mann-Whitney rank sum test, p < 0.05; Fig. 2C). However, as the experiment progressed, colonies in the grazing bottles increased to sizes significantly larger than those in the controls (Day 7 and Day 9, Mann-Whitney rank sum test, $\mathrm{p}<0.05)$. The geometric mean colony diameter in the grazing bottles was 24 and $16 \%$ larger than that in the controls on Day 7 and Day 9, respectively. Despite ingestion, $N$. scintillans did not grow on $P$. globosa, and the final mean $\pm \mathrm{SD}$ concentration of $N$. scintillans in the grazing bottles was $7.8 \pm 0.5 \mathrm{ml}^{-1}$. Using Frost's equations (Frost 1972), we estimated that $N$. scintillans had a clearance rate of 18 to $23 \mu \mathrm{l}$ ind. ${ }^{-1} \mathrm{~d}^{-1}$ and an ingestion rate of 1051 to 1343 cells ind ${ }^{-1} \mathrm{~d}^{-1}$ (for a grazer concentration of 7.8 to 10 ind. $\mathrm{ml}^{-1}$ ), or 9.8 to $12.5 \mathrm{ng} \mathrm{C}$ ind. ${ }^{-1} \mathrm{~d}^{-1}$ (based on 

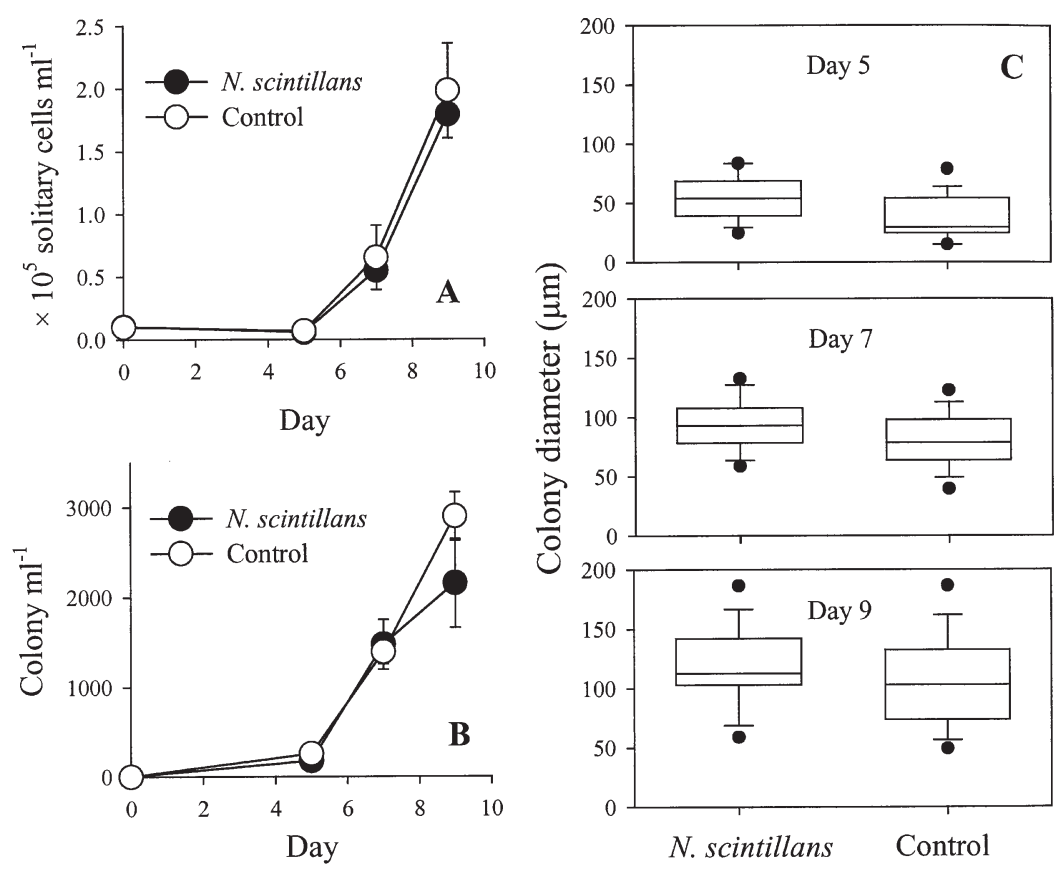

Fig. 1. Effects of Noctiluca scintillans on colony development in Phaeocystis globosa (Expt Noc 1). (A) Concentration of P. globosa solitary cells (mean \pm standard deviation [SD]). (B) Concentration of P. globosa colonies (mean \pm SD). (C) Box plots of P. globosa colony diameters showing 5, 10, 25, 50, 75, 90 and 95 percentiles. For initial experimental conditions see Table 1. For statistical test results see 'Results'
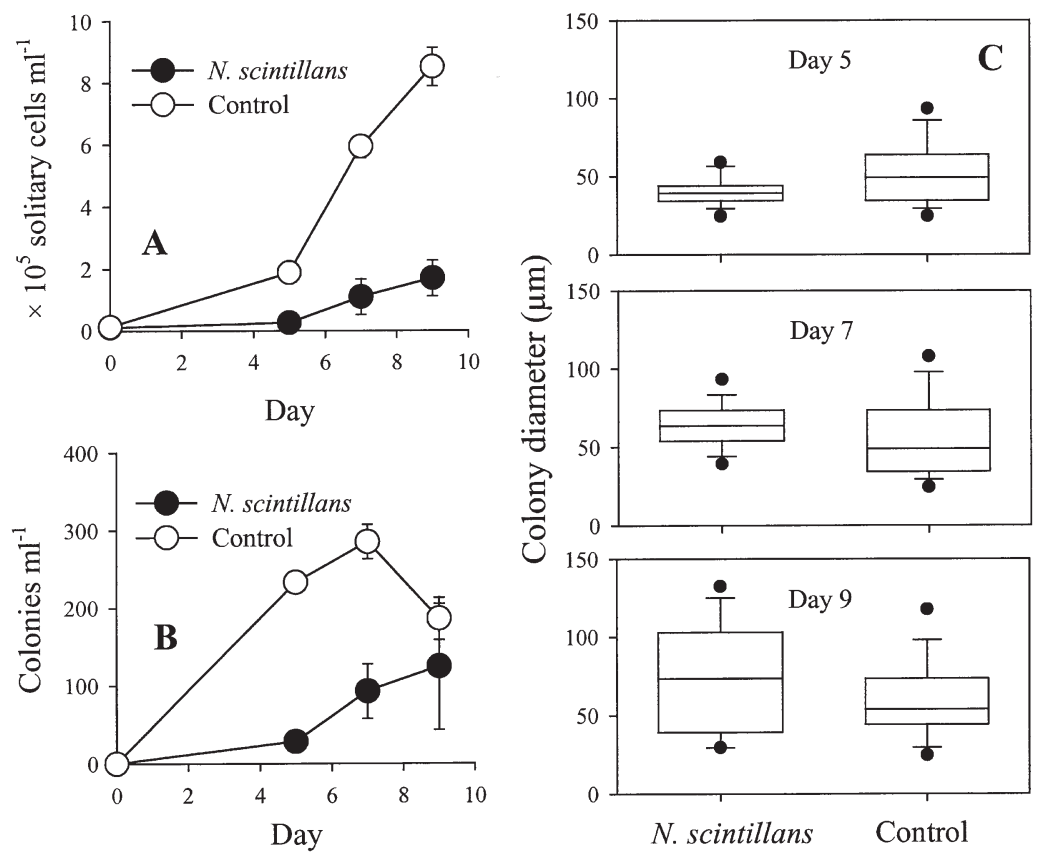

Fig. 2. Effects of Noctiluca scintillans on colony development in Phaeocystis globosa (Expt Noc 2). For explanations see Fig. 1. For statistical test results see 'Results'
$9.3 \mathrm{pg} \mathrm{C} \mathrm{cell}{ }^{-1}$ from Tang et al. 2001) during the $9 \mathrm{~d}$ period. This clearance rate is within the general clearance rates for $N$. scintillans (0.24 to $240 \mu \mathrm{l}$ ind. ${ }^{-1} \mathrm{~d}^{-1}$; Kiørboe \& Titelman 1998) but an order of magnitude lower than some of the clearance rates obtained by Weisse \& Scheffel-Möser for N. scintillans feeding on Phaeocystis sp. cells (cited in Weisse et al. 1994).

\section{Effects of Gyrodinium dominans on colony development}

In Expt Gyro 1, growth of solitary cells was reduced by Gyrodinium dominans during the first $6 \mathrm{~d}$ (Fig. 4A) but recovered when the number of $G$. dominans began to decline (Table 3, Fig. 4C). G. dominans continued to decrease and became undetectable after 9 to $12 \mathrm{~d}$. The concentrations of colonies in the grazing bottles exceeded those in the controls after 9 d (Table 3), after which the number of colonies declined in all treatments (Fig. 4B). Between the high and the low grazing treatments, the colony concentrations were different only on Day 6 (Table 3). Colony diameters were not different between the 2 grazing treatments. However, enhancement of colony size in the grazing treatments was evident after $6 \mathrm{~d}$ (Table 3). The geometric mean colony diameter was 5 to $68 \%$ larger in the grazing bottles than in the controls, and the colonies were more heterogeneous in size in the controls (Fig. 4D).

More pronounced effects were observed in Expt Gyro 2 when we started with higher concentrations of Gyrodinium dominans but maintained similar initial predator-to-prey ratios (Table 1). The presence of $G$. dominans clearly delayed the increase of solitary cells relative to the controls (Fig. 5A). Colony concentration in the grazing bottles remained low during the first $6 \mathrm{~d}$, after which the number of colonies in the low grazing treatment increased sharply and exceeded that in the other treatments. In contrast, the concentration of colonies in the high grazing treatment remained lower than that in one or both of the other treatments throughout the experiment (Fig. 5B). Enhancement of colony size due to grazing was evident after 6 and $8 d$ in the high and low grazing 


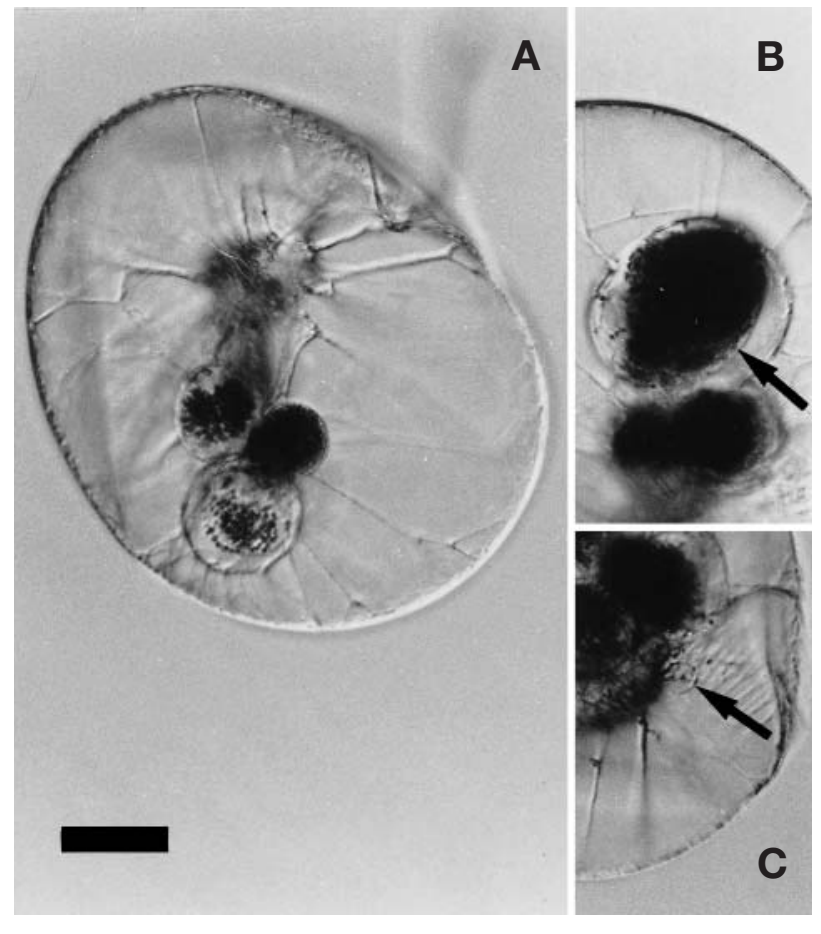

Fig. 3. Noctiluca scintillans with ingested Phaeocystis globosa. (A) P. globosa inside food vacuoles of N. scintillans (scale bar $=250 \mu \mathrm{m})$. (B) Arrow shows an ingested P. globosa colony with visible colony envelope. (C) Arrow shows a single $P$. globosa cell inside a food vacuole

number and log colony diameter (Fig. 6). We then applied the regression to the geometric mean colony diameters for each sampling date to calculate the mean concentrations of $P$. globosa cells in colonial form and compared that to the average concentrations of solitary cells. In both experiments, $\leq 31 \%$ of the cells in the controls were in colonial form (Fig. 7). Grazing by G. dominans increased the proportions of colonial cells after an initial time lag (Day 2 in Expt Gyro 2). The proportions of colonial cells reached maximum (67 to $92 \%$ ) in the grazing treatments within $6 \mathrm{~d}$, then decreased as $G$. dominans decreased but remained higher than that in the controls (Fig. 7).

treatments, respectively (Fig. 5C, Table 4), during which time $G$. dominans was in decline (Fig. 5C) and Phaeocystis globosa solitary cells resumed exponential growth (Fig. 5A). The measured $\mathrm{pH}$ of the medium ( 7.85 to 7.97 ) was not different between the control and the grazing bottles (1-way ANOVA, p > 0.05). At the end of the experiment, colonies in the high and low grazing treatments were, respectively, 4 and 3 times as large as colonies in the controls (Table 4). Colony size was also significantly different between the high and the low grazing treatments between Day 10 and Day 14 .

\section{Partition of Phaeocystis globosa cells between colonial form and solitary form}

In the grazing experiments with Gyrodinium dominans (Expts Gyro 1 and Gyro 2), we measured on several occasions the number of Phaeocystis globosa cells per colony. Log colony cell number was linearly related to log colony diameter, and the slope of the regression lines was not significantly different between the grazing treatments and the controls (data not shown). We subsequently combined all measurements and derived a regression relationship between log colony cell
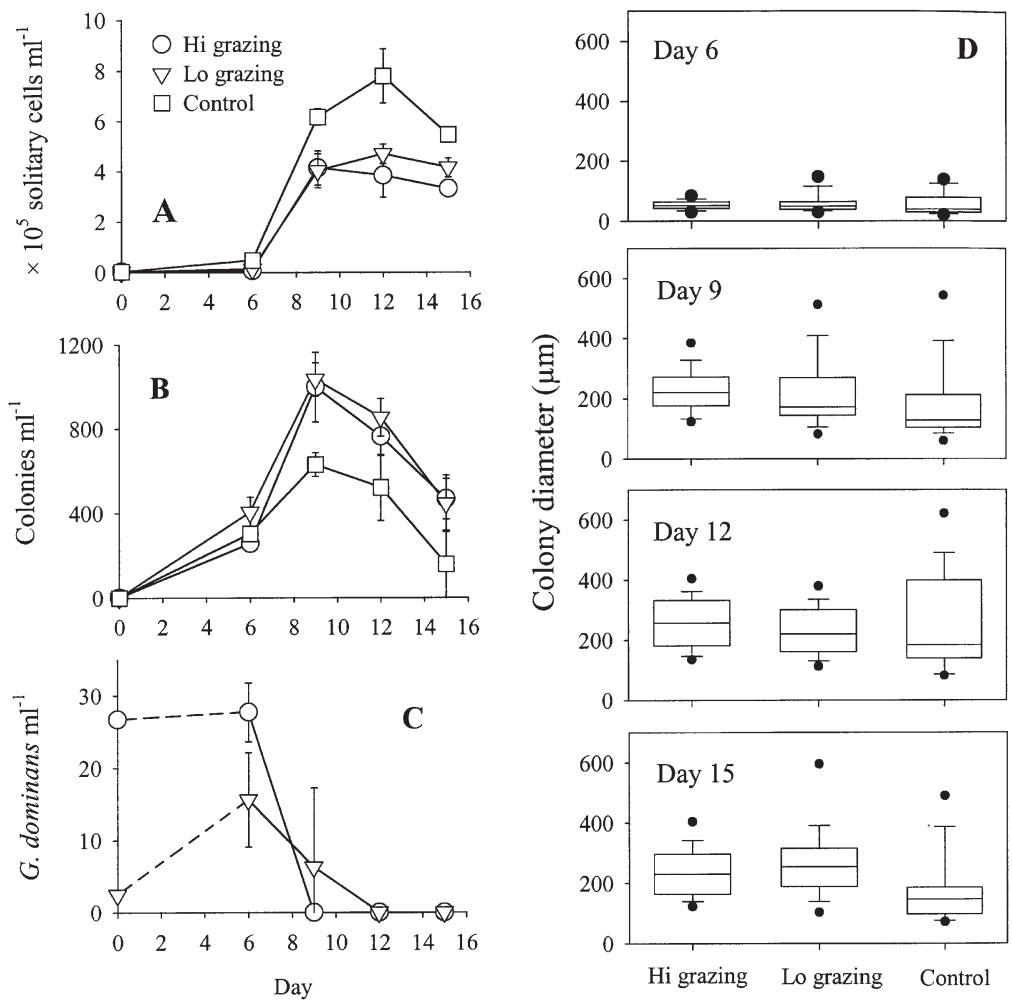

Fig. 4. Effects of Gyrodinium dominans on colony development in Phaeocystis globosa (Expt Gyro 1). (A) Concentration of P. globosa solitary cells (mean $\pm \mathrm{SD}$ ). (B) Concentration of P. globosa colonies (mean $\pm \mathrm{SD}$ ). (C) Concentration of $G$. dominans (mean $\pm \mathrm{SD}$ ). (D) Box plots of $P$. globosa colony diameters showing 5, 10, 25, 50, 75, 90 and 95 percentiles. For initial experimental conditions see Table 1. For statistical test results see Table 3. Hi: high grazing treatment; Lo: low grazing treatment 
Table 3. Expt Gyro 1 with Gyrodinium dominans (Fig. 4). Comparison of Phaeocystis globosa between high grazing treatment $(\mathrm{H})$, low grazing treatment (L) and control (C). Specific growth rate of solitary cells is calculated assuming exponential growth between consecutive sampling dates. All parameters are tested for significance at $p=0.05$. ns: no significant differences

\begin{tabular}{|c|c|c|c|c|c|}
\hline \multirow{2}{*}{ Parameters } & \multirow{2}{*}{ Statistical test } & \multicolumn{4}{|c|}{ — Day } \\
\hline & & 6 & 9 & 12 & 15 \\
\hline $\begin{array}{l}\text { Solitary cell specific } \\
\text { growth rate }\left(\mathrm{d}^{-1}\right)\end{array}$ & $\begin{array}{l}\text { 1-way ANOVA } \\
\text { followed by Tukey test }\end{array}$ & $\mathrm{C}>\mathrm{L}>\mathrm{H}$ & $\mathrm{H}>\mathrm{L}>\mathrm{C}$ & ns & ns \\
\hline $\begin{array}{l}\text { Colony conc. } \\
\left(\text { colonies } \mathrm{ml}^{-1}\right)\end{array}$ & $\begin{array}{l}\text { 1-way ANOVA } \\
\text { followed by Tukey test }\end{array}$ & $\mathrm{L}>\mathrm{H}$ & $\begin{array}{l}\mathrm{L}>\mathrm{C} \\
\mathrm{H}>\mathrm{C}\end{array}$ & $\mathrm{L}>\mathrm{C}$ & ns \\
\hline $\begin{array}{l}\text { Colony diameter } \\
(\mu \mathrm{m})\end{array}$ & $\begin{array}{l}\text { Kruskal-Wallis test } \\
\text { followed by Dunn's } \\
\text { pairwise comparison }\end{array}$ & $\begin{array}{l}\mathrm{L}>\mathrm{C} \\
\mathrm{H}>\mathrm{C}\end{array}$ & $\begin{array}{l}\mathrm{L}>\mathrm{C} \\
\mathrm{H}>\mathrm{C}\end{array}$ & ns & $\begin{array}{l}\mathrm{L}>\mathrm{C} \\
\mathrm{H}>\mathrm{C}\end{array}$ \\
\hline $\begin{array}{l}\text { Ratio of geometric } \\
\text { mean colony diameter }\end{array}$ & $\begin{array}{l}\mathrm{H}: \mathrm{C} \\
\mathrm{L}: \mathrm{C}\end{array}$ & $\begin{array}{l}1.10 \\
1.15\end{array}$ & $\begin{array}{l}1.44 \\
1.28\end{array}$ & $\begin{array}{l}1.16 \\
1.05\end{array}$ & $\begin{array}{l}1.52 \\
1.68\end{array}$ \\
\hline
\end{tabular}

\section{Test for toxicity in Phaeocystis globosa}

Grazer-adapted Phaeocystis globosa solitary cells were collected from the preincubation bottles when Gyrodinium dominans decreased to $<25 \mathrm{ml}^{-1}$ after 9 d (Fig. 8A). When these grazer-adapted cells were fed to new G. dominans, the protozoan showed positive initial growth over $2 \mathrm{~d}$, and the growth rate was not different from that feeding on reference cells (Student's $t$-test, $\mathrm{p}>0.05$; Fig. 8B). Thus, our data do not indicate development of cellular toxicity in $P$. globosa after exposure to grazing.

\section{Starvation and recovery experiment with Gyrodinium dominans}

After depletion of solitary cells, the concentration of Gyrodinium dominans declined steadily over $4 \mathrm{~d}$, and the specific rate of decline was $-0.28 \mathrm{~d}^{-1}$ at the end of the starvation period (Fig. 9A). When the starving $G$. dominans were fed a low concentration of Phaeocystis globosa solitary cells $\left(2 \times 10^{4} \mathrm{ml}^{-1}\right)$ in the recovery vials, the recovery growth rate was low and variable $\left(0.07 \pm 0.22 \mathrm{~d}^{-1}\right.$; mean $\left.\pm \mathrm{SD}\right)$. When fed a high concentration of $P$. globosa cells $\left(2 \times 10^{5} \mathrm{ml}^{-1}\right)$, the recovery growth rate was negative, at $-0.14 \mathrm{~d}^{-1}$ (Fig. 9B).
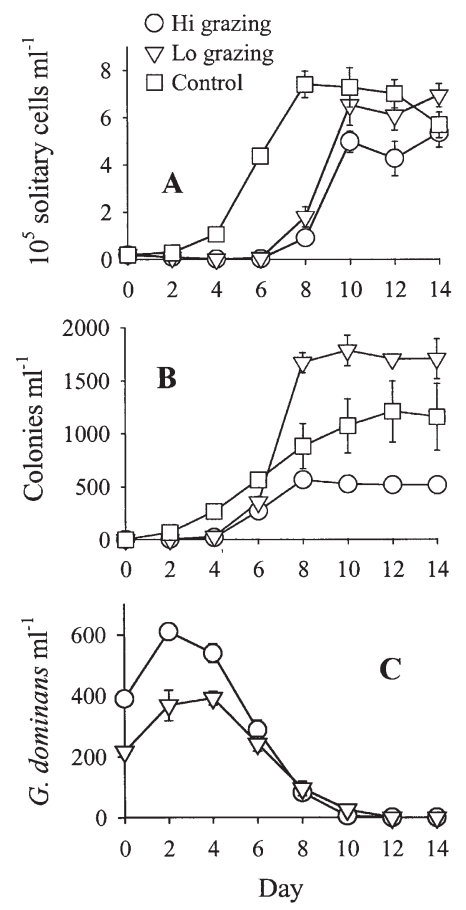

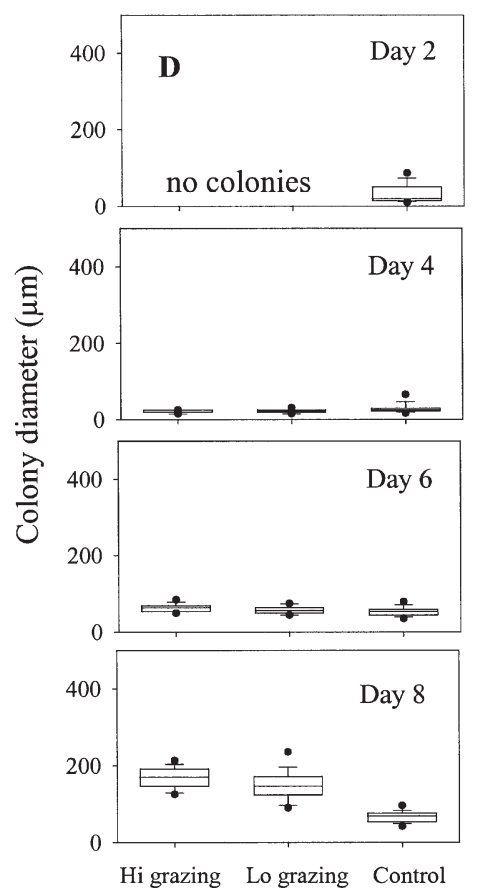

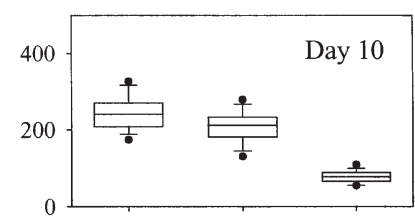

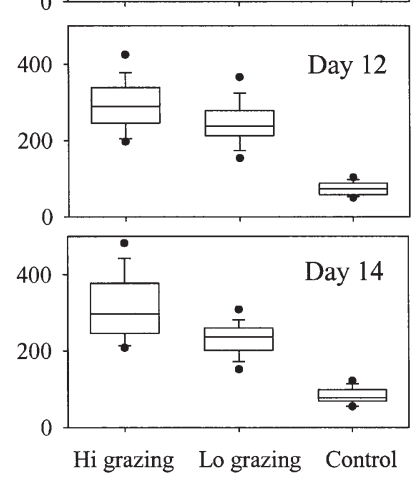

Fig. 5. Effects of Gyrodinium dominans on colony development in Phaeocystis globosa (Expt Gyro 2). For explanations see Fig. 4. For statistical test results see Table 4 
Table 4. Expt Gyro 2 with Gyrodinium dominans (Fig. 5). Comparison of Phaeocystis globosa between H, L and C. Specific growth rate of solitary cells is calculated assuming exponential growth between consecutive sampling dates. All parameters are tested for significance at $\mathrm{p}=0.05$. ${ }^{*}$ No colonies in grazing bottles on Day 2

\begin{tabular}{|c|c|c|c|c|c|c|c|}
\hline \multirow{2}{*}{ Parameters } & \multicolumn{7}{|c|}{ - Day } \\
\hline & 2 & 4 & 6 & 8 & 10 & 12 & 14 \\
\hline Solitary cell specific growth rate $\left(\mathrm{d}^{-1}\right)$ & $\begin{array}{l}\mathrm{C}>\mathrm{L} \\
\mathrm{C}>\mathrm{H}\end{array}$ & $\begin{array}{l}\mathrm{C}>\mathrm{L} \\
\mathrm{C}>\mathrm{H}\end{array}$ & ns & $\begin{array}{l}\mathrm{L}>\mathrm{C} \\
\mathrm{H}>\mathrm{C}\end{array}$ & $\mathrm{H}>\mathrm{L}>\mathrm{C}$ & ns & $\mathrm{H}>\mathrm{C}$ \\
\hline Colony conc. (colonies $\mathrm{ml}^{-1}$ ) & C only* & $\begin{array}{l}\mathrm{C}>\mathrm{L} \\
\mathrm{C}>\mathrm{H}\end{array}$ & $\begin{array}{l}\mathrm{C}>\mathrm{L} \\
\mathrm{C}>\mathrm{H}\end{array}$ & $\begin{array}{l}\mathrm{L}>\mathrm{C} \\
\mathrm{L}>\mathrm{H}\end{array}$ & $\mathrm{L}>\mathrm{C}>\mathrm{H}$ & $\mathrm{L}>\mathrm{C}>\mathrm{H}$ & $\mathrm{L}>\mathrm{C}>\mathrm{H}$ \\
\hline Colony diameter $(\mu \mathrm{m})$ & C only* & $\begin{array}{l}\mathrm{C}>\mathrm{L} \\
\mathrm{C}>\mathrm{H}\end{array}$ & $\begin{array}{l}\mathrm{H}>\mathrm{C} \\
\mathrm{H}>\mathrm{L}\end{array}$ & $\begin{array}{l}\mathrm{H}>\mathrm{C} \\
\mathrm{L}>\mathrm{C}\end{array}$ & $\mathrm{H}>\mathrm{L}>\mathrm{C}$ & $\mathrm{H}>\mathrm{L}>\mathrm{C}$ & $\mathrm{H}>\mathrm{L}>\mathrm{C}$ \\
\hline Ratio of geometric mean colony diameter & $\begin{array}{l}\mathrm{H}: \mathrm{C}^{*} \\
\mathrm{~L}: \mathrm{C}^{*}\end{array}$ & $\begin{array}{l}0.76 \\
0.80\end{array}$ & $\begin{array}{l}1.25 \\
1.12\end{array}$ & $\begin{array}{l}2.60 \\
2.32\end{array}$ & $\begin{array}{l}3.11 \\
2.63\end{array}$ & $\begin{array}{l}3.98 \\
3.32\end{array}$ & $\begin{array}{l}4.02 \\
2.95\end{array}$ \\
\hline
\end{tabular}

\section{DISCUSSION}

\section{Grazing and colony development in Phaeocystis globosa}

Colony formation is a common feature among different Phaeocystis species. A conceivable advantage of colony formation is to counteract grazing of the solitary cells due to the size of the colonies and mechanical toughness of the colony envelope. In the present study, grazing by the heterotrophic dinoflagellates Noctiluca scintillans and Gyrodinium dominans on the solitary cells affected the colony development in Phaeocystis

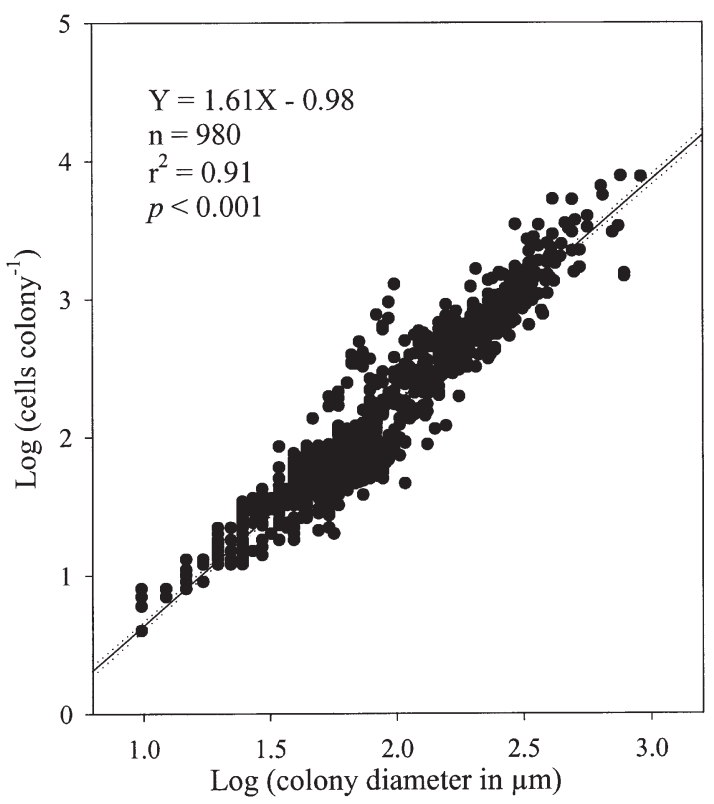

Fig. 6. Log-log plots of cell number versus diameter of Phaeocystis globosa colonies. Linear regression and the 95\% confidence intervals are shown. Equations for the regression lines, sample sizes (n), explained variances $\left(\mathrm{r}^{2}\right)$ and significant level (p) are also presented globosa. High initial grazing pressure by N. scintillans led to a reduced number of colonies, whereas with $G$. dominans in most cases grazing appeared to increase the number of colonies. In all experiments (high and low grazing pressures), colony size increased in the grazing treatments relative to the controls after 5 to $8 \mathrm{~d}$. Colony formation as a defensive response to grazing is common in the freshwater alga Scenedesmus sp. However, there are major differences in the colony structure between Scenedesmus sp. and P. globosa. Scenedesmus sp. colonies are usually limited to no more than a few cells per colony (Lürling \& van Donk 1997, Lürling 1999); thus, the effects of grazing are
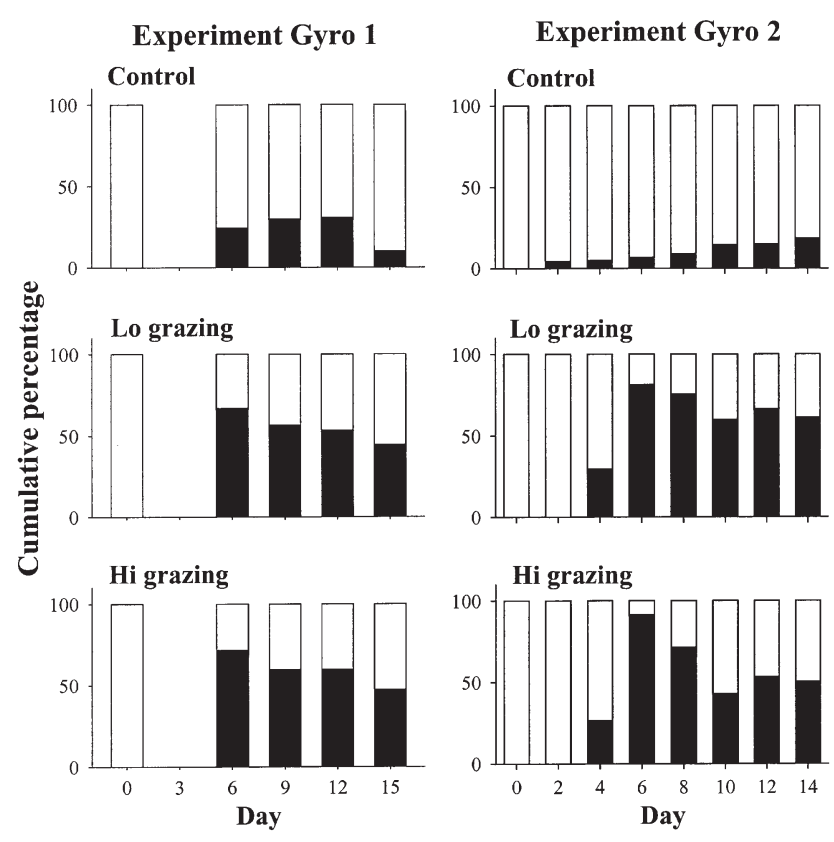

Fig. 7. Partition of Phaeocystis globosa cells between solitary form (white bars) and colonial form (black bars) in the experiments with Gyrodinium dominans (Gyro 1 and Gyro 2). For initial experimental conditions see Table 1 

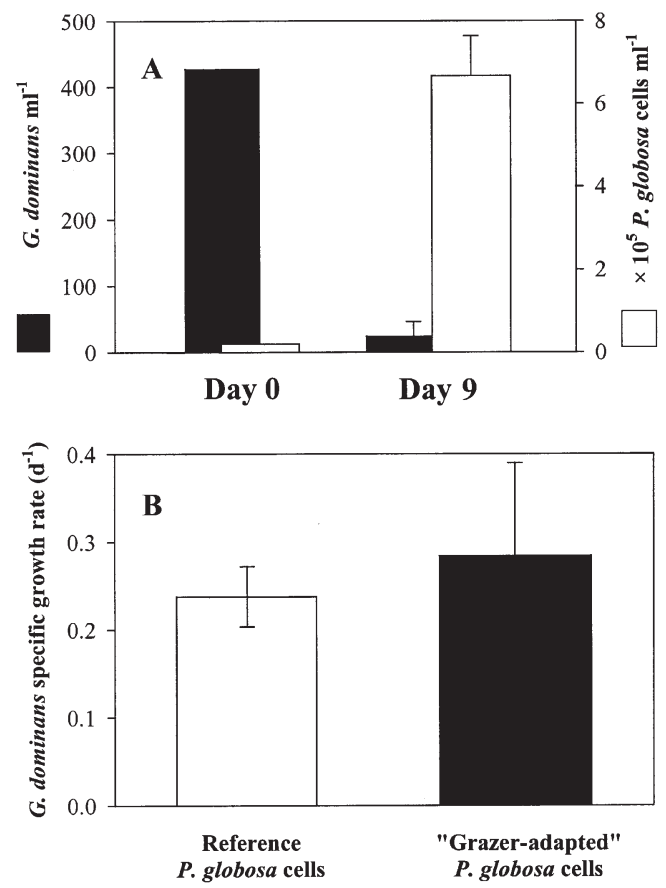

Fig. 8. Test for toxic effects of Phaeocystis globosa cells on Gyrodinium dominans. (A) 'Grazer-adapted' P. globosa cells were collected after $9 \mathrm{~d}$ when $G$. dominans decreased to low concentration. (B) Growth of new G. dominans feeding on grazer-adapted $P$. globosa cells. P. globosa cells without prior exposure to grazers were used as reference cells. Growth rates of $G$. dominans were not significantly different between the 2 treatments (Student's $t$-test, $p>0.05$ ). Error bars are $\mathrm{SD}$ of triplicate experiments

largely manifest as an increase in colony abundance (Lürling 1998). In a P. globosa colony, individual cells are arranged on the peripheral mucous envelope while the colony interior remains hollow (Van Rijssel et al. 1997). Such an arrangement allows the colony to maximize its size with any given number of cells. Also, the colony size and the number of cells per colony are highly variable. In our experiments, some colonies reached $>200 \mu \mathrm{m}$ in diameter with hundreds of individual cells. Thus, grazing effects may be reflected in colony size, colony abundance or both. Such was the case in Expt Gyro 2, in which colony concentration in the high grazing treatment was lower than that in the control and the low grazing treatment. At first glance this seems to contradict the notion that grazing enhances colony formation. However, if one considers the larger colony size in the high grazing treatment, it becomes clear that a higher proportion of P. globosa cells was in colonial form relative to the controls (Fig. 7).

There also appeared to be a difference in how Phaeocystis globosa responded to the 2 protozoan grazers, which had different feeding behaviors. Gyro-
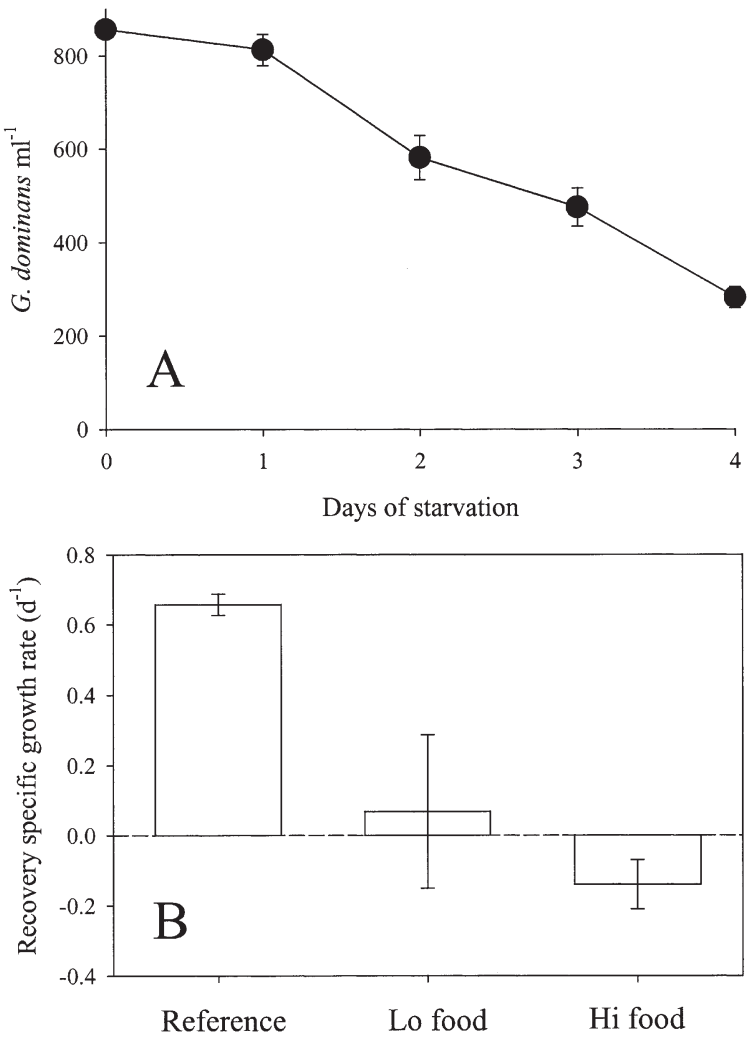

Fig. 9. Starvation and recovery of Gyrodinium dominans. (A) Decrease of G. dominans during starvation. (B) Recovery growth of $G$. dominans (after $4 \mathrm{~d}$ of starvation) when fed high $\left(2 \times 10^{5} \mathrm{ml}^{-1}\right)$ and low $\left(2 \times 10^{4} \mathrm{ml}^{-1}\right)$ concentrations of Phaeocystis globosa solitary cells for 2 consecutive days. For comparison, 'Reference' bar is included to indicate the specific growth rate of G. dominans under constant food concentration $\left(2 \times 10^{4} \mathrm{ml}^{-1}\right.$ P. globosa solitary cells) for $>5 \mathrm{~d}$ (data from Tang et al. 2001). Error bars are SD of triplicate experiments

dinium dominans swims and captures prey with a tow filament typical of many naked heterotrophic dinoflagellates (Hansen \& Caldo 1999). Retraction of the filament brings the prey into contact with $G$. dominans, which then engulfs the prey whole through the sulcus. Noctiluca scintillans, on the other hand, does not swim but encounters its prey by ascending and descending through the water column (Kiørboe \& Titelman 1998). Prey is captured by a mucus structure attached to the tentacle and engulfed through a cytostome (Hansen \& Caldo 1999 and references therein). Since both grazers engulf their prey whole, their ability to ingest Phaeocystis globosa colonies is limited by their cell size. In our experiments with $N$. scintillans (1.3 $\mathrm{mm}$ cell size), the colony size range between the grazing treatments and the controls largely overlapped (Figs. $1 \& 2$ ); therefore, it cannot be ruled out that the significant difference in colony sizes between the grazing treatments and the controls was a result of $N$. scintillans remov- 
ing small colonies. In fact, microscopic observations showed that $N$. scintillans was capable of ingesting $P$. globosa colonies (Fig. 3). In contrast, the small G. dominans $(15 \mu \mathrm{m})$ did not appear to ingest colonies. High grazing pressure from $G$. dominans resulted in an overall colony size range higher than that in the controls (Expt Gyro 2, Fig. 5D), showing that there was an absolute increase in colony size in response to grazing. In Expts Gyro 1 and Gyro 2, P. globosa colony size continued to increase, and the percentage of cells in colonial form remained high relative to the controls even after the die-off of $G$. dominans in the grazing bottles. Therefore, colony formation in natural P. globosa populations may reflect the influence of grazing activities in the present as well as in the past environment.

The linear log-log relationship between colony cell number and colony diameter that we observed is highly significant ( $p<0.001)$, and the slope (1.61) is comparable to the 1.53 derived by Rousseau et al. (1990) for Phaeocystis sp. A slope $<2$ indicates that the packing of cells per unit colony surface area decreases as the colonies increase in size, perhaps an adaptation to or a result of diffusion limitation of nutrients across the boundary layer of the colonies (Ploug et al. 1999). The lack of difference in the slopes of the regression lines between grazing and control treatments suggests that, while grazing by Gyrodinium dominans induces the colonies to grow larger, the packing of the colonial cells remains unchanged.

\section{Potential costs and benefits of colony formation in Phaeocystis globosa}

It should be noted that colony formation took place in our controls even when grazers were absent. Recent studies have shown that Phaeocystis sp. colonies outcompete solitary cells under high nitrate (Riegman et al. 1992) and high irradiance (Peperzak 1993) conditions. The mucilaginous matrix also serves as energy and trace element storage; thus, colony formation may offer certain benefits when external environments are favorable (Lancelot \& Rousseau 1994). Our study clearly shows that colony formation in P. globosa was not necessarily initiated by grazing, but the process was enhanced by grazing (in terms of colony abundance and colony size). In the experiments with Gyrodinium dominans, P. globosa solitary cells were initially depleted by the grazers but recovered once the grazers began to die off. The decline of the grazers was not due to cellular toxicity of $P$. globosa but to starvation after the initial depletion of solitary cells. In the recovery experiment, after an extended period of starvation, $G$. dominans recovered at a very low rate $\left(0.07 \mathrm{~d}^{-1}\right)$ when offered $2 \times 10^{4} \mathrm{ml}^{-1}$ of $P$. globosa cells.
This recovery growth rate was much lower than the growth rate $\left(0.66 \mathrm{~d}^{-1}\right)$ of non-starving $G$. dominans feeding on the same concentration of P. globosa (Fig. 9; Tang et al. 2001). Protozoans have been shown to reduce their metabolism in response to food depletion, and prolonged starvation leads to slow recovery (Fenchel 1990). Thus, an obvious advantage of colony formation in $P$. globosa is to provide a refuge for the individual cells, depriving the protozoan grazers of food, and the subsequent slow recovery of the grazers allows $P$. globosa to regain growth at a high rate. Interestingly, starving $G$. dominans had a negative recovery growth rate when offered a high concentration of $P$. globosa $\left(2 \times 10^{5} \mathrm{ml}^{-1}\right)$. Negative growth of dinoflagellates under super-saturating ambient algal concentrations is not uncommon, perhaps a result of elevated $\mathrm{pH}$ in the medium exceeding their physiological tolerance (Schmidt \& Hansen 2001). Thus, these observations help explain why, in the colony development experiments, G. dominans continued to decline when $P$. globosa solitary cells regained growth in the grazing bottles.

If (enhanced) colony formation is a strategy of morphological defense, there should be a cost associated with the process as predicted by the defense theory. One possible cost could be a reduced growth rate in the colonial form. To test this hypothesis, we compared the apparent specific growth rate of solitary cells and colonial cells in Expts Gyro 1 and Gyro 2 during the period when both morphotypes were present (Table 5). For the grazing treatments, only the data after 8 to $9 \mathrm{~d}$ were used when reduction of solitary cell growth rate due to grazing was negligible. The apparent specific growth rates of solitary cells were calculated based on the average solitary cell concentrations, assuming an exponential growth between consecutive sampling dates. Mean colony cell numbers were estimated from the geometric mean colony diameters (see regression equation in Fig. 6), then multiplied by the colony concentrations to give the mean concentrations of colonial cells. The apparent specific growth rates of colonial cells were calculated assuming an exponential growth between consecutive sampling dates. These growth rates are labeled 'apparent' because the calculations did not take into account release of solitary cells from colonies; nevertheless, such an omission would only underestimate the true growth rate of colonial cells while overestimating the true growth rate of solitary cells. In both experiments, the apparent specific growth rates of colonial cells were initially high but then declined, perhaps due to colony disintegration and detachment of cells from aging colonies (Rousseau et al. 1994). Contrary to our expectation, the apparent specific growth rate was not different between solitary cells and colonial cells (paired $t$-test, $\mathrm{p}>0.05$ ). Thus, 
Table 5. Comparison of apparent specific growth rates of solitary cells and colonial cells in the experiments with Gyrodinium dominans (Gyro 1 and Gyro 2; Figs. 4 \& 5). Growth rates were calculated assuming exponential growth during each period. For the grazing treatments, comparisons are done for the periods when grazing loss of solitary cells was negligible (see Figs. 4 \& 5). For initial experimental conditions see Table 1

\begin{tabular}{|c|c|c|c|c|}
\hline Expt. & Treatment & Period (d) & $\begin{array}{l}\text { Apparent specif } \\
\text { Solitary cells }\end{array}$ & $\begin{array}{c}\text { growth rate }\left(\mathrm{d}^{-1}\right) \\
\text { Colonial cells }\end{array}$ \\
\hline \multirow[t]{3}{*}{ Gyro 1} & Control & $\begin{array}{c}6-9 \\
9-12 \\
12-15\end{array}$ & $\begin{array}{r}0.86 \\
0.08 \\
-0.12\end{array}$ & $\begin{array}{r}0.95 \\
0.09 \\
-0.58\end{array}$ \\
\hline & Low grazing & $\begin{array}{r}9-12 \\
12-15\end{array}$ & $\begin{array}{r}0.05 \\
-0.04\end{array}$ & $\begin{array}{r}0.01 \\
-0.16\end{array}$ \\
\hline & High grazing & $\begin{array}{r}9-12 \\
12-15\end{array}$ & $\begin{array}{l}-0.03 \\
-0.05\end{array}$ & $\begin{array}{l}-0.03 \\
-0.21\end{array}$ \\
\hline \multirow[t]{4}{*}{ Gyro 2} & Control & $\begin{array}{c}2-4 \\
4-6 \\
6-8 \\
8-10 \\
10-12 \\
12-14\end{array}$ & $\begin{array}{r}0.67 \\
0.71 \\
0.26 \\
-0.01 \\
-0.02 \\
-0.10\end{array}$ & $\begin{array}{l}0.73 \\
0.90 \\
0.41 \\
024 \\
0.00 \\
0.03\end{array}$ \\
\hline & Low grazing & $\begin{array}{r}8-10 \\
10-12 \\
12-14\end{array}$ & $\begin{array}{r}0.64 \\
-0.03 \\
0.07\end{array}$ & $\begin{array}{r}0.24 \\
0.09 \\
-0.04\end{array}$ \\
\hline & High grazing & $\begin{array}{r}8-10 \\
10-12 \\
12-14\end{array}$ & $\begin{array}{r}0.86 \\
-0.08 \\
0.11\end{array}$ & $\begin{array}{l}0.21 \\
0.11 \\
0.05\end{array}$ \\
\hline & & & \multicolumn{2}{|c|}{ Paired $t$-test, $\mathrm{p}=0.46$} \\
\hline
\end{tabular}

mean colony diameter was $305 \mu \mathrm{m}$ in the present study. According to a modeling study, in a low turbulence environment, as was the case in our experiments (shear rate $\approx 0.01 \mathrm{~s}^{-1}$ ), the thickness of DBL for orthophosphate and inorganic nitrogen are scaled almost linearly to the diameter of colonies smaller than $400 \mu \mathrm{m}$ (Ploug et al. 1999). Therefore, colony formation would have increased the DBL thickness by up to $\sim 60$ times relative to a $5 \mu \mathrm{m}$ solitary cell in our experiments. Increased DBL would arguably reduce nutrient uptake by the colonial cells. However, the colonial cells did not suffer from a reduced growth rate relative to the solitary cells in our experiments (Table 5), perhaps because our experiments were conducted in a $\mathrm{N}$ - and P-replete condition (based on the total P. globosa cell concentrations, $\sim 2 \%$ of $\mathrm{N}$ and $0.5 \%$ of $\mathrm{P}$ in the medium would have been consumed in all experiments). Thus, it remains to be shown how $P$. globosa responds to grazing when $\mathrm{N}$ and $\mathrm{P}$ or other nutrients become limiting.
Phaeocystis globosa cells did not suffer from reduced growth in colonial form, and the potential cost of colony formation must be sought elsewhere.

In their studies with Scenedesmus acutus, Lürling \& van Donk (2000) noted that colonial cells had comparable growth rates as solitary cells, but the higher sinking rate of the colonies may drive the cells to the less favorable deeper waters. Van Boekel reported that young and healthy Phaeocystis globosa colonies had sinking rates as high as 5 to $7 \mathrm{~m} \mathrm{~d}^{-1}$ (cited in Riegman \& van Boekel 1996). However, based on observations of our P. globosa cultures, most colonies maintained nearly neutral buoyancy. Also, the hollow structure of the colonies should allow the colonies to increase in size with only a slight increase in sinking rate. Thus, it is unlikely that sinking would be a substantial cost of colony formation in our experiments. Molecular study has shown that haploid Phaeocystis sp. cells occur only in the solitary phase (Vaulot et al. 1994). Although the biological significance of ploidy of different Phaeocystis sp. life stages remains unclear, one could argue that colony formation reduces the cell's ability to undergo sexual reproduction. Another potential cost of colony formation is reduced nutrient uptake due to an increased diffusive boundary layer (DBL) around the colonies (Ploug et al. 1999). The maximum geometric

\section{Grazing and colony size spectrum in natural Phaeocystis sp. populations}

Formation of mucilaginous colonies is one of the most striking features of Phaeocystis sp. Past research efforts have focused on how physical and chemical factors affect the initiation of colony formation (e.g. Peperzak 1993, Cariou et al. 1994; also review by Rousseau et al. 1994), but they did not address the issue of what controls the size of the colonies. Unlike many other colony-forming phytoplankters, a natural Phaeocystis sp. population contains colonies of a wide size range, from tens of micrometers to a few millimeters (Rousseau et al. 1990). A continual increase in colony size inevitably poses the problems of reduced nutrient uptake and enhanced sinking rate, which must be compensated for by certain benefits. Thus, a logical question is: What controls the colony size spectrum of a Phaeocystis sp. population? Our present study has shown that initial grazing by protozoans on Phaeocystis globosa solitary cells led to an increase in colony size. Nevertheless, the colonies in our experiments still covered a relatively narrow size range. If increased colony size is a defense strategy, as indicated by our results, the colony size spectrum would 
depend on the grazing pressure and the food size preference of the ambient grazers. In natural waters, different groups of grazers coexist with Phaeocystis sp. and many of them graze on Phaeocystis sp. cells and colonies to different extents. For example, many protozoan species can feed on solitary cells at high rates (e.g. Weisse \& Scheffel-Möser 1990, Tang et al. 2001), but their consumption of colonies is less common (e.g. the present study). Many copepod species can graze on solitary cells (Tang et al. 2001 and references therein) and colonies of particular sizes (Weisse 1983, Huntley et al. 1987, Hansen et al. 1990, 1994). Thus, the wide size spectrum of natural Phaeocystis sp. colonies is perhaps a result of grazing pressure from different grazers with different food size preference. Temporal and geographical variations in Phaeocystis sp. colony abundance and size spectra may hence reflect differences in the trophodynamic processes within the pelagic food web.

Acknowledgements. The study is supported by a Carlsberg Foundation (Denmark) research fellowship awarded to K.W.T. and Danish Natural Science Research Council Grant No. 9801393 awarded to Dr. Thomas Kiørboe. This study was inspired by a discussion with Dr. Paul Wassmann, whose encouragement is much appreciated. The authors also thank Dr. P. von Dassow for providing Noctiluca scintillans and Kristine Hansen for technical assistance. Drs. T. Kiørboe, P. J. Hansen, P. Verity, J. Dolan and an anonymous reviewer provided constructive comments.

\section{LITERATURE CITED}

Aanesen RT, Eilertsen HC, Stabell OB (1998) Light-induced toxic properties of the marine alga Phaeocystis pouchetii towards cod larvae. Aquat Toxicol 40:109-121

Agrawal AA (1998) Algal defense, grazers, and their interactions in aquatic trophic cascades. Acta Oecol 19:331-337

Berenbaum MR (1995) The chemistry of defense: theory and practice. Proc Natl Acad Sci USA 92:2-8

Cariou V, Casotti R, Birrien JL, Vaulot D (1994) The initiation of Phaeocystis colonies. J Plankton Res 16:457-470

Fenchel T (1990) Adaptive significance of polymorphic life cycles in protozoa: responses to starvation and refeeding in two species of marine ciliates. J Exp Mar Biol Ecol 136: 159-177

Frangoulis C, Belkhiria S, Goffart A, Hecq JH (2001) Dynamics of copepod faecal pellets in relation to a Phaeocystis dominated phytoplankton bloom: characteristics, production and flux. J Plankton Res 23:75-88

Frost BW (1972) Effects of size and concentration of food particles on the feeding behavior of the marine planktonic copepod Calanus pacificus. Limnol Oceanogr 17:805-815

Guillard RRL, Hargraves PE (1993) Stichochrysis immobilis is a diatom, not a chrysophyte. Phycologia 32:234-236

Hamm CE, Simson DA, Merkel R, Smetacek V (1999) Colonies of Phaeocystis globosa are protected by a thin but tough skin. Mar Ecol Prog Ser 187:101-111

Hansen B, Tande KS, Berggreen UC (1990) On the trophic fate of Phaeocytis pouchetii (Hariot). III. Functional responses in grazing demonstrated on juvenile stages of
Calanus finmarchicus (Copepoda) fed diatoms and Phaeocystis. J Plankton Res 12:1173-1187

Hansen B, Verity P, Falkenhaug T, Tande KS, Norrbin F (1994) On the trophic fate of Phaeocystis pouchetii (Harriot). V. Trophic relationships between Phaeocystis and zooplankton: an assessment of methods and size dependence. J Plankton Res 16:487-511

Hansen FC, Reckermann M, Klein Breteler WCM, Riegman R (1993) Phaeocystis blooming enhanced by copepod predation on protozoa: evidence from incubation experiments. Mar Ecol Prog Ser 102:51-57

Hansen PJ (1991) Quantitative importance and trophic role of heterotrophic dinoflagellates in a coastal pelagial food weeb. Mar Ecol Prog Ser 73:253-261

Hansen PJ, Caldo AJ (1999) Phagotrophic mechanisms and prey selection in free-living dinoflagellates. J Eukaryot Microbiol 46:382-389

Hay ME (1996) Marine chemical ecology: what's known and what's next? J Exp Mar Biol Ecol 200:103-134

Huntley M, Tande K, Eilertsen HC (1987) On the trophic fate of Phaeocystis pouchetii (Hariot). II. Grazing rates of Calanus hyperboreus (Krøyer) on diatoms and different size categories of Phaeocystis pouchetii. J Exp Mar Biol Ecol 110:197-212

Kiørboe T, Titelman J (1998) Feeding, prey selection and prey encounter mechanisms in the heterotrophic dinoflagellate Noctiluca scintillans. J Plankton Res 20:1615-1636

Lancelot C, Rousseau V (1994) Ecology of Phaeocystis: the key role of colony forms. In: Green JC, Leadbeater BSC (eds) The haptophyte algae. Clarendon Press, Oxford, p 229-245

Lancelot C, Keller MD, Rousseau V, Smith WO Jr, Mathot S (1998) Autecology of the marine haptophyte Phaeocystis sp. In: Anderson DM, Cembella AD, Hallegraeff GM (eds) Physiological ecology of harmful algal blooms. SpringerVerlag, Berlin, p 209-224

Lewis WM Jr (1986) Evolutionary interpretations of allelochemical interactions in phytoplankton algae. Am Nat 127:184-194

Lürling M (1998) Effect of grazing-associated infochemicals on growth and morphological development in Scenedesmus acutus (Chlorophyceae). J Phycol 34:578-586

Lürling M (1999) Grazer-induced coenobial formation in clonal cultures of Scenedesmus obilquus (Chlorococcales, Chlorophyceae). J Phycol 35:19-23

Lürling M, van Donk E (1997) Morphological changes in Scenedesmus induced by infochemicals released in situ from zooplankton grazers. Limnol Oceanogr 42:783-788

Lürling M, van Donk E (2000) Grazer-induced colony formation in Scenedesmus: are there costs to being colonial? Oikos 88:111-118

Mole S (1994) Trade-offs and constraints in plant-herbivore defense theory: a life-history perspective. Oikos 71:3-12

Nakamura Y, Suzuki S, Hiromi J (1995) Growth and grazing of a naked heterotrophic dinoflagellate, Gyrodinium dominans. Aquat Microb Ecol 9:157-164

Naustvoll LJ (2000) Prey size spectra in naked heterotrophic dinoflagellates. Phycologia 39:448-455

Peperzak L (1993) Daily irradiance governs growth rate and colony formation of Phaeocystis (Prymnesiophyceae). J Plankton Res 15:809-821

Ploug H, Stolte W, Jørgensen BB (1999) Diffusive boundary layers of the colony-forming plankton alga Phaeocystis sp.: implications for nutrient uptake and cellular growth. Limnol Oceanogr 44:1959-1967

Riegman R, van Boekel W (1996) The ecophysiology of Phaeocystis globosa: a review. J Sea Res 35:235-242 
Riegman R, Noordeloos A, Cadée GC (1992) Phaeocystis blooms of the continental zones of the North Sea. Mar Biol 112:479-484

Rousseau V, Mathot S, Lancelot C (1990) Calculating carbon biomass of Phaeocystis sp. from microscopic observations. Mar Biol 107:305-314

Rousseau V, Vaulot D, Casotti R, Cariou V, Lenz J, Gunkel J, Baumann M (1994) The life cycle of Phaeocystis (Prymnesiophyceae): evidence and hypotheses. J Mar Syst 5: 23-39

Schmidt LE, Hansen PJ (2001) Allelopathy in the Prymnesiophyte Chrysochromulina polylepis: effect of cell concentration, growth phase and pH. Mar Ecol Prog Ser 216: $67-81$

Schoemann V, de Baar HJW, de Jong JTM, Lancelot C (1998) Effects of phytoplankton blooms on the cycling of manganese and iron in coastal waters. Limnol Oceanogr 43: $1427-1441$

Stabell OB, Aanesen RT, Eilertsen HC (1999) Toxic peculiarities of the marine alga Phaeocystis pouchetii detected by in vivo and in vitro bioassay methods. Aquat Toxicol 44: $279-288$

Stoecker DK, Putt M, Moisan T (1995) Nano- and microplankton dynamics during the spring Phaeocystis sp. bloom in McMurdo Sound, Antarctica. J Mar Biol Assoc

Editorial responsibility: John Dolan,

Villefranche-sur-Mer, France
UK 75:815-832

Tang KW, Jakobsen HH, Visser AW (2001) Phaeocystis globosa (Prymnesiophyceae) and the planktonic food web: feeding, growth and trophic interactions among grazers. Limnol Oceanogr 46:1860-1870

Van Rijssel M, Hamm C, Gieskes WWC (1997) Phaeocystis globosa (Prymnesiophyceae) colonies: hollow structures built with small amounts of polysaccharides. Eur J Phycol 32:185-192

Vaulot D, Birrien JL, Marie D, Casotti R, Veldhuis MJ, Kraay GW, Chritiennot-Dinet MJ (1994) Morphology, ploidy, pigment composition, and genome size of cultured strains of Phaeocystis (Prymnesiophyceae). J Phycol 30:1022-1035

Verity PG (2000) Grazing experiments and model simulations of the role of zooplankton in Phaeocystis food webs. J Sea Res 43:317-343

Weisse T (1983) Feeding of calanoid copepods in relation to Phaeocystis pouchetii blooms in the German Wadden Sea area off Sylt. Mar Biol 74:87-94

Weisse T, Scheffel-Möser U (1990) Growth and grazing loss rates in single-celled Phaeocystis sp. (Prymnesiophyceae). Mar Biol 106:153-158

Weisse T, Tande K, Verity P, Hansen F, Gieskes W (1994) The trophic significance of Phaeocystis blooms. J Mar Syst 5: $67-79$

Submitted: October 1, 2001; Accepted: December 12, 2001

Proofs received from author(s): March 26, 2002 